Published in Strategic Management Journal, 29, 1371-1394, 2008.

\title{
CONTROL OF INTELLECTUAL ASSETS IN CLIENT RELATIONSHIPS: IMPLICATIONS FOR INNOVATION $^{1}$
}

\author{
Aija Leiponen \\ Cornell University \\ Department of Applied Economics and Management \\ 251 Warren Hall \\ Ithaca, NY 14853-7801, USA \\ Tel. +1-607-255-7588 \\ Fax +1-607-255-9984 \\ e-mail: aija.leiponen@cornell.edu \\ Running title: CONTROL OF INTELLECTUAL ASSETS
}

\section{SUMMARY}

This empirical study of business-to-business service firms examines the determinants and effects of control rights to intellectual assets in a property rights theoretic framework. Regression analyses using survey data suggest that service suppliers who retain control over their intellectual output are more innovative. In long-term relationships, service firms' clients may thus be better off balancing their need to control outsourced activities with the suppliers' incentives to invest in learning and innovation. Additionally, and aligned with property rights theoretic predictions, service suppliers' bargaining power and their indispensability in service projects are positively associated with their ability to retain control rights. In contrast, innovation capabilities are not very significant in determining control rights allocation between service suppliers and their clients.

Key words: Knowledge, innovation, intellectual property rights, supply relationships, business services, property rights theory

\footnotetext{
${ }^{1}$ This research was supported by the Innovation Networks research program of SITRA, the Finnish Foundation for R\&D. Early stages of this research benefited from comments by the participants in the 2002 meetings of the International Schumpeter Society meeting and the International Society for New Institutional Economics, and the 2003 Academy of Management meeting. Hazem Daouk's generous help in programming the conditional likelihood model using RATS is gratefully acknowledged. Daniel Simon, Jeff Prince, Constance Helfat, and two anonymous reviewers provided invaluable comments. Remaining errors are mine alone.
} 


\section{Introduction}

The growing literature on the knowledge-based view of the firm has argued that practices for managing knowledge assets can have substantial effects on firm performance (e.g., Wernerfelt, 1984; Dierickx \& Cool, 1989; Teece, Pisano, \& Shuen, 1997). This paper focuses on the governance of knowledge assets in client-supplier relationships. Governance matters for performance, because, in contrast to physical assets, property rights to valuable knowledge assets may be difficult to establish and enforce in knowledge-based interaction with partners. In other words, involuntary transfers of knowledge — spillovers — are difficult to avoid in close supply relationships. Indeed, governance arrangements are often put in place in these kinds of relationships to minimize spillovers (Oxley, 1997). The novelty of this paper is to empirically examine the incentive effects associated with such attempts to control intellectual assets and their use in supply relationships.

In the economics of innovation, the ability to control knowledge is seen to create incentives to invest in research and development (R\&D) (Levin et al., 1987). Then, the allocation of rights to control intellectual assets created in supply relationships can have strategic ramifications. The party who obtains the rights to a newly created knowledge asset will be motivated to improve it, build on it, and use it in a variety of applications. Innovation activities are thus implicated by the allocation of control rights to intellectual assets in firms' external relationships. Viewing the appropriability problem in supply relationships as an instance of incomplete contracting (cf. Elfenbein \& Lerner, 2003), this paper argues that the arrangements to control the intellectual assets created or used in a supply relationship between two firms affect the partners' incentives to build on that knowledge. Empirical analysis to follow suggests that these arrangements are a significant driver of innovation in knowledge-based business services, 
but it is argued that the results obtained here are applicable in a broader range of industries and collaborative innovation settings. Control rights allocation in supply relationships is thus an important context of intellectual property rights strategy.

In rapidly changing business environments, success often depends on collaboration between firms. This study focuses on the interaction between knowledge-intensive business service (KIBS) providers and their client firms. Business service firms are knowledge intensive when their service operations rely on professional knowledge and either generate new knowledge themselves (e.g., engineering and R\&D services) or act as knowledge intermediaries for their clients (e.g., computer and communication services) (Miles \& Boden, 2000; Löwendahl, 1997). Miles et al. (1995), for example, include services such as software and other computerrelated services, management consulting, technical engineering, design, and $R \& D$ consulting in this category. Actual measures of knowledge intensity of firms in the sample used here indicate that, on average, $33 \%$ of employees in these firms have higher education degrees (college or higher) and that firms' service development investments average about 3\% of sales revenue. These numbers are much higher than those found in the manufacturing sector (means for the whole manufacturing sector in a representative sample are $11 \%$ and $1.2 \%$, respectively; see SF, 2000).

Business services have recently attracted a lot of attention due to their rapid growth in the OECD countries. For example, according to Tomlinson's (2000) macroeconomic input-output analysis, the share of KIBS inputs in the UK economy has increased from 5\% in 1970 to $25 \%$ in 1990. This growth may be caused by a growing demand for knowledge-intensive services and by changes in the division of labor among industries. Availability of outsourcing arrangements have provided manufacturing firms with the option to shift many service activities to external 
providers (O'Farrell, 1995). Consequently, specialized business service suppliers have become a significant source of knowledge and innovation for manufacturing firms.

Knowledge-intensive business services also represent a fascinating context for study because most of their transactions involve knowledge, varying from codified technological blueprints to difficult-to-communicate organizational knowledge (Hansen, Nohria, \& Tierney, 1999; Hargadon \& Sutton, 1997). As a result, the processes for managing and creating knowledge are central for competitive advantage in these industries. This study explores how business service firms create knowledge and structure knowledge transactions. Focusing on the effects of the allocation of formal control rights to intellectual assets, the goal of this paper is to generate insights applicable in the more general area of the management of knowledge-based supply relationships. In some business service industries, particularly industrial design, the norm is to yield the control rights to the clients. This serves to protect clients' strategically sensitive product development activities in which the service supplier participates. However, in many other industries, control rights may not be quite as critical for the client. For example, software or other information technology service supply relationships are a possible field of application of the results obtained here.

The current study can be viewed as an empirical application of the economic incomplete contracting theory. Its contribution is that, in addition to assessing the determinants of the allocation of control rights in a new empirical setting, the effects on innovation outcomes are directly assessed. We empirically examine the argument originally made by Aghion and Tirole (1994) that control rights to intellectual assets are associated with incentives and ability to invest in the creation of new knowledge. Control-right allocation may therefore have dynamic effects on the performance of the supply relationship and the partners themselves. Control rights to 
jointly created knowledge assets should socially optimally be allocated to the partner that is the best positioned to make noncontractible investments in the project and, later on, build on and improve the asset. However, bargaining power differences may lead to inefficient allocation of the rights if the powerful partner is not the more important one in making noncontractible investments. The next section builds on extant literature and derives empirical hypotheses concerning the determinants and effects of the allocation of control rights to knowledge assets between vertically related organizations. Section 3 describes the business service dataset, empirical analysis of which is carried out in section 4 . Section 5 discusses the results and draws conclusions.

\section{Knowledge Creation and Client Relationships in Business Services: Literature Review and Empirical Hypotheses}

Firms engage in $R \& D$ alliances or outsourcing arrangements to gain access to proprietary information and competences (Hagedoorn, 1993; Hamel, Doz, \& Prahalad, 1989, 1991; Kale, Singh, \& Perlmutter, 2000; Kogut, 1988). Indeed, much of the previous strategic management research on supply relationships (e.g., Asanuma, 1989; Dyer, 1996; Dyer \& Nobeoka, 2000) and strategic alliances (e.g., Mowery, Oxley, \& Silverman, 1996; Anand \& Khanna, 2000) focuses on the accumulation and exchange of knowledge in network relationships, abstracting from the role of intellectual or other property rights. For example, Mowery et al. (1996) rely on patent data but use them to examine the role of firms' technological capability portfolios in alliance formation.

Another stream of research within the alliance literature highlights the appropriability problem inherent in strategic alliances, where intellectual property rights are likely to provide 
incomplete protection for strategic assets. For example, Kale et al. (2000) discuss the importance of relational capital in protecting strategically important assets in alliances, and Teece (1986), Pisano (1989), and Oxley (1997; also Oxley and Sampson 2004) have suggested that by choosing carefully how to organize joint $\mathrm{R} \& \mathrm{D}$, firms can attenuate appropriability hazards. Intellectual assets created in collaborative relationships may thus give rise to competitive advantage, but attention needs to be paid to their management and governance. Much of the above research concludes that more protection for intellectual assets generally is better, although the benefits of protection need to be balanced against the cost of governance. Similarly, economic studies of the sources and implications of appropriability (Levin et al., 1987; Cohen \& Levinthal, 1989) highlight the idea that in the absence of protection for the returns on innovation activities, R\&D investment levels will be suboptimal. These studies are thus concerned with the incentives created by the rights to control the results of innovation activities.

In summary, existing economic and management literatures suggest that control of intellectual property is central for firms to invest in R\&D and engage in alliances and networks, and, consequently, each actor should control their intellectual assets maximally. Empirical research has not explicitly examined the idea that firms could write contracts strategically to create incentives for their partners to exert effort in noncontractible activities. Namely, when each firm individually maximizes the control of intellectual property, innovation incentives are not necessarily optimally distributed in the economy. In some instances, both partners are better off when control rights are allocated to the party that is the best positioned to innovate.

Extant research on networks and alliances typically emphasizes informal mechanisms of governance (e.g., Dyer \& Singh, 1998). An exception is Sampson (2004) who argues that misaligned alliance governance may depress the incentives to innovate. However, the focus of 
her study is to estimate the total costs of misaligned governance, not their incentive implications. Aligned with Sampson's (2004) work, and with that of Poppo and Zenger (2002), this paper argues that even though informal mechanisms of governance are vital for the success of business relationships, formal mechanisms usefully codify rules and principles that govern the relationship. The theoretical lens to analyze alliance contracts has often been transaction cost economics, whereas this paper suggests that other models of incomplete contracting ${ }^{2}$ can be applied in the study of knowledge-based interfirm relationships. In particular, the property rights theory might be of value to scholars of alliance and supply relationships (see Foss \& Foss, 2005).

The theoretical framework developed here consists of three arguments from the property rights theory of the firm (Grossman \& Hart, 1986; Hart \& Moore, 1990; see also Hart, 1995). First, allocation of control rights should optimally depend on the partners' relative abilities to contribute to and utilize the jointly created knowledge asset. The party that is more effective at creating, using, or building valuable new knowledge on the asset should obtain the control rights to it. However, second, bargaining power differences may distort the control right allocation in practice (Aghion \& Tirole, 1994). Third, the allocation of rights to intellectual assets in supplier relationships matters to the parties, because control rights have significant effects on the incentives to invest in noncontractible activities, such as innovation. We will elaborate each of the three arguments below.

The first of the three main arguments concerns how control rights should optimally get allocated. Hart and Moore's model (1990) shows that the party whose noncontractible investments are indispensable for the project should hold the property rights to the project assets

\footnotetext{
${ }^{2}$ Transaction cost theory can be seen as one framework among the many informal and formal models that all examine the causes and effects of incomplete contracts.
} 
in order to generate best possible (second-best) incentives for the parties to make noncontractible investments. An agent is indispensable when the underlying assets have no effect on the marginal productivity of the other parties' investments without the indispensable partner-the agent's human capital is critical for the project outcome. Indispensability can be assessed from the point of view of the service provider's direct contributions to client projects. For example, Elfenbein and Lerner (2003) found in a study of Internet portal alliances that the allocation of ownership to key assets was influenced by the relative efforts of the alliance parties (see also Leiponen, 2006b). Aligned with earlier research, we hypothesize that service firms that are in a position to greatly influence the project outcome are more likely to retain control of intellectual assets:

Hypothesis 1 Service firms that are relatively more indispensable in client projects are more likely to retain control rights to intellectual assets in client relationships than firms that provide less critical inputs.

Furthermore, it is proposed here that, optimally, future interactions of the parties should be considered. In a long-term, ongoing, service relationship, it is not only the efficiency in the current project that matters; implications of current learning for future projects should also be taken into account in making decisions about the organization of joint projects. In other words, optimizing the organization of joint activities should take place in an intertemporal framework (e.g., Baker, Gibbons, \& Murphy, 2002). While the data available do not allow explicitly testing dynamic models, we argue that in an empirical context where competitiveness is based on knowledge creation and repeated interactions are highly valued because of search and contracting costs, client firms should care about the incentives for future knowledge creation they provide for their suppliers. Therefore, they should consider letting potentially highly innovative service providers retain control rights. 
In view of the dataset used here, we assume that firms with existing procedures and capabilities to innovate are well positioned to contribute to current and future creative projects (cf. Lerner \& Merges, 1998, consider patent holdings of the R\&D firm). Even though relatively few business service firms have institutionalized R\&D units, many of the sampled service firms expend substantial human resources in the development of new or improved services. Service development often involves rotating or ad hoc project teams that put aside time for research (e.g., market research and other external information sourcing) and meetings to discuss and develop new service concepts. However, some organizations have a permanent team that is in charge of service development, and technical service firms (engineering or R\&D services) may even have an R\&D facility. We assume that service providers that invest highly in these kinds of service development activities are more likely to have accumulated innovation capabilities that enable them to make unique intellectual contributions in client relationships. As a consequence, they have a higher probability of retaining control rights:

Hypothesis 2 Service firms with stronger capabilities to innovate are more likely to retain control rights to intellectual output than service firms with weak or no innovation capabilities.

The second theoretical argument developed by Aghion and Tirole (1994) suggests that, in practice, ownership shares in collaborative arrangements may reflect bargaining power of the partners rather than the importance of their contributions. For example, the relative financial positions of the collaborating firms may influence ownership allocation outcomes and create inefficiencies. In particular, if the more powerful party is not the more indispensable one for the outcome of the project, property rights are likely to get misallocated. An empirical example from Lerner and Merges (1998) is a situation where a biotechnology company that is highly cash constrained and competes against other similar technology providers allies with a larger 
pharmaceutical company. Even if the biotechnology company were much more important for the success of the project, Aghion and Tirole would predict that the pharmaceutical company obtains and holds on to the control rights to innovations arising from the alliance. This is individually rational for the company_it may obtain a higher payoff this way_but it doesn't provide socially optimal incentives and thus will not maximize total welfare. In other words, it would be possible for both parties to receive a higher payoff if there were mechanisms to provide optimal incentives and distribute the marginal payoff to both parties. In reality, however, the expected returns from innovation will be reduced because the biotechnology firm has suboptimal investment incentives.

This theory thus sheds light on the question of what prevents firms from optimally allocating control rights in a service relationship. According to Aghion and Tirole, the chief source of this type of inefficiency is differences in bargaining power. If the service provider's client is large and prominent, it is highly likely to obtain intellectual control rights in the relationship, independent of the optimal configuration. As a result, the service provider may have suboptimal incentives to invest in learning and build on the knowledge jointly created. However, in principle, it is equally possible that the service firm retains control rights even if its client has higher innovation or contribution potential, provided that the service firm is more powerful. This might be the case if the service firm is larger or financially stronger than its clients. Then the clients' incentives would be compromised. The empirical hypothesis is the following:

Hypothesis 3 Bargaining power of business service firms is positively associated with their ability to retain control rights to intellectual assets in client relationships.

In the empirical examination we cannot directly test whether inefficiency is indeed created by the allocation of control rights, but we will examine whether proxies for bargaining power explain control rights allocation. If our empirical measures for bargaining power statistically 
significantly explain control rights outcomes, we have indirect evidence of inefficiency. Control rights to intellectual assets are then distributed based on bargaining power instead of the parties' potential contributions. A possible reason for this outcome is that it is individually rational for the more powerful party to retain the rights. Then, it may be impossible to design mechanisms that provide socially optimal incentives and a pareto improving division of payoffs. However, it is also conceivable, considering the extant managerial intellectual property literature that emphasizes control, that firms prefer to err on the side of excessive control, because this reduces the uncertainty about the future value of the knowledge asset. When this is the case, firms would be better off if they adopted a more long-term view of the service relationship and included suppliers' incentive considerations in their strategic calculations.

The final, third, argument implies that control rights related to intellectual assets are associated with incentives and ability to invest in the creation of new knowledge. The property rights theory holds that when contracts are incomplete, the party who owns or controls an asset will be the "residual claimant"-they will collect the residual returns on their own noncontractible investments and will therefore be motivated to make these investments (Hart \& Moore, 1990). Learning and innovation are typically to a significant degree noncontractible. As a result, control rights allocation influences the performance of the supply relationship and the partners themselves. Business service firms that do not retain control rights to their accumulated knowledge are constrained in terms of innovation opportunities. For example, new insights gained in management consulting projects cannot be built on and marketed to other firms if the first client requires exclusivity within its industry. Similarly, a new technology developed by an $R \& D$ service provider to solve the problem of one client cannot be utilized in another client's project if the first client obtains all intellectual property rights. Under these circumstances, the 
service provider has little incentive to put forth extra effort—-beyond what is specified in the (incomplete) service contract - and they will be less innovative in their service relationships.

However, it is important to recognize that it is not always optimal for the service provider to obtain the control rights. When the client is more relevant for the project or relationship outcome, i.e., they are in a position to better influence the outcome, they should obtain the rights to control key knowledge assets. Even in this case, however, control right allocation will influence the service provider's innovation incentives. At the margin, thus, there exist firms that would have innovated if it wasn't for the contractual arrangements they had entered that reduce their ability to benefit from the investments in innovation:

Hypothesis 4 Service firms that retain control rights to intellectual assets are more likely to innovate than firms that yield control rights to their clients.

Moreover, the effect of control right allocation on innovation incentives is expected to be stronger with respect to introduction of new services than with respect to improving existing services. New service introductions are riskier and costlier than service improvements from the service provider's point of view, and, without the right to control the use of relevant intellectual assets, they may not be profitable for the firm. Being able to control and benefit from the outcome is thus even more important for new service development projects than it is for incremental service improvement projects. This leads to the fifth and last hypothesis:

Hypothesis 5 Retaining control rights is more strongly associated with firms making new service introductions than with those making service improvements.

It is also worth considering whether control rights and innovation outcomes matter for business service firms. The relevance of control rights depends on the assumption that innovation is indeed an important competitive goal for business service firms. Existing empirical evidence suggests this is the case: business service providers report higher levels of innovativeness than 
firms in the manufacturing sector ( $45 \%$ of the sampled business service firms launched new services; $26 \%$ of manufacturing firms launched new products in a representative sample; see SF, 1998). Summary discussion of 15 case studies by Miles et al. (1995) supports this view. Furthermore, in the current survey dataset, business service executives were asked to assess how important a set of factors were for the competitive advantage of their firm. Learning on the job and reputation were rated the most important factors, as argued in other studies (Löwendahl, 1997; DeBandt, 1996; Holmström, 1985). Service improvement and innovation were regarded about as important as formal education, training on the job, or marketing. ${ }^{3}$ Similarly, Löwendahl argues that innovation and creation of new services are important strategic goals for certain types of professional services (1997: 126). According to these studies, then, innovation is a relevant goal for many business service firms. If control rights to intellectual assets enable business service firms to innovate, firms will care about control rights.

\section{The Business Service Dataset}

This section describes the survey dataset and constructs estimation variables to be used in the empirical analysis. The data were collected through a mail survey of Finnish knowledgeintensive business service firms, administered by the Research Institute of the Finnish Economy. A questionnaire, developed after semi-structured interviews with 16 chief executives from leading Finnish business service firms and respective industry associations, ${ }^{4}$ was mailed to 445

\footnotetext{
3 On a scale of 0-3 (not important-very important), 160 business service executives responded that the competitiveness of their firm depends on learning on the job (mean score 2.8), reputation (2.7), training (2.4), improvements to existing services (2.3), formal education (2.3), knowledge residing in teams (2.2), marketing (2.1) and innovation (2.0). Thus, in this survey, introduction of new services and improvement of existing services were most often considered to be important or very important determinants of competitive advantage.

${ }^{4}$ The interviews were carried out before designing the survey questionnaire and they were semistructured, lasting 13 hours. Interviewees included CEOs or business development managers of the largest firms in each industry and a
} 
firms. Questionnaire recipients were identified from the lists obtained from Statistics Finland of the 100 largest firms in the six industries studied. Focusing on the largest firms was necessary because of the small average size of firms in these industries and the emphasis on organizational aspects in this study. Questionnaires were addressed to CEOs, although, in about $10 \%$ of the cases, other managers such as those responsible for business or service development responded. Forty-six of the firms were found to be invalid: they did not participate in the targeted industries, had merged, or had gone out of business. Service subsidiaries of manufacturing corporations were also excluded.

The advantages of using this source of data include unusually detailed information of both innovation activities and client relationships for a broad set of business service firms and industries. The downside is that the level of analysis is the firm. Ideally, property-rights theoretic predictions should be analyzed at the level of transactions or projects, but it is very difficult to obtain these kinds of data for a cross-section of firms. Instead, our survey instrument asked respondents to describe their contractual practices and other aspects of their relationships with key clients. According to supplementary interviews, in ongoing service relationships, contractual frames are typically not rewritten for each project. Instead, the first project contract is carefully negotiated while subsequent contracts only modify the project specifics and fill in any gaps observed. One of the very important initial negotiations concern control rights, in particular, how clients' sensitive knowledge assets are protected. Contractual practices regarding control rights thus tend to be relatively stable over time and across projects with the same client. ${ }^{5}$ This

set of smaller companies based on suggestions by industry association contacts. More detailed information about these interviews can be obtained from the author.

${ }^{5}$ However, because the survey instrument contained no direct questions about this, we cannot rule out the possibility that control rights are modified more often. 
approach allows us to analyze contractual practices at the firm level and match them with other firm-level data.

Innovation activities and outcomes are typically firm-level, as opposed to transactionlevel, phenomena. The survey dataset here aggregates transactions to a few key clients of each respondent. This allows us to estimate, first, the determinants of "typical" contractual practices, and, second, the effects of these contractual arrangements on innovation outcomes. The limitations of this approach include reliance on subjective assessments and aggregated tendencies, which both are likely to add noise to the data and make it more difficult to obtain significant results. However, there is no apparent reason why these data would be systematically biased. The survey questions, developed after interviews with business service CEOs, ask about contractual dimensions typically covered in service contracts. It should thus be relatively straightforward for respondents to answer these questions.

The survey response rate was $42 \%$. Based on information from Statistics Finland, the survey respondents represented slightly larger firms than the mean in the target group ( 29 vs. 24 employees). ${ }^{6}$ However, in terms of profitability (sales per employee), firms in the sample actually performed slightly worse than the targeted group. The sample thus does not seem to be biased toward more successful firms. Results may be affected by the bias toward larger firms, however, to the extent that contractual practices influence firms' probability of innovation differently for large and small service firms. This will be assessed in the empirical analysis.

Additional data are available for the technical service industries in the sample. Table 1 presents information from the representative Finnish Community Innovation Survey (CIS) (SF,

\footnotetext{
${ }^{6}$ This average number of employees of the surveyed firms, 29, is different from that in table 1 because the Statistics Finland data are a few years older.
} 
1998), which included the technical services industry (NACE 742: engineering and architectural services). Unfortunately, the other business service industries examined here were not included in the CIS sample. Available descriptive statistics for technical services, excluding architecture and construction, are presented in the last column of table 1. Compared to the CIS data, the firms in the survey data of engineering services used here are about equally large in terms of employees. ${ }^{7}$ This suggests that the possible large firm bias found earlier is not very significant. Furthermore, engineering firms in the current sample are on average about equally innovative as those in the CIS sample. The sampling method and data collection approach thus do not seem to have created any systematic biases, assuming that other industries in the sample are about as representative as engineering services.

Descriptive statistics of the main dependent and explanatory variables are displayed in table 1 . There is considerable variation across industries. Firms are typically rather small in industrial design ${ }^{8}$ and electrical engineering. Propensity to export also varies by industry. However, at the firm level, the picture is even more diverse: there are a handful of technologically-oriented firms in the sample that export all of their sales, while most firms export little. The business group variable is a binary indicator for firms that are subsidiaries of a service group. These firms are thus wholly or majority owned by other service firms or holding companies.

The main variables of interest characterize the external control of service firms' resources in terms of typical contractual features with the most important or "key" clients. Unfortunately, we have no information about how large a portion of sales these key clients represent. However, according to the supplementary interview evidence, most business service firms strive to form

\footnotetext{
${ }^{7}$ The sales numbers are not directly comparable because of the different years of observation.
} 
long-term relationships with important clients, because search and asymmetric information costs are substantial. As a result, relationships with key clients are likely to represent both a significant share of the service firm's sales and a stream of repeated transactions.

We focus on the allocation of control rights to project output and partial exclusivity restrictions regarding supply to the client's competitors. These two aspects of external control were identified as relevant in the interviews with business service executives. The variable "output control rights to client" refers to a survey question asking how often the rights to control knowledge assets created in joint projects with key clients are transferred to the client (never, sometimes, often, or always). If the service firm always agrees to give the control rights to the service output—design, process plan, or technology—to key clients, it then gives up the possibility to re-use some of this accumulated knowledge. Another survey question asked how often the service firm agrees with key clients that it will not supply similar services to the clients' competitors (never, sometimes, often, or always). These partial exclusivity clauses constrain the service supplier's growth opportunities. These two control rights variables will first be used as dependent variables in the analyses of the determinants of control rights allocation and then as explanatory variables for innovation output.

Handing control rights to clients is a rather common practice in business services (table 1). The two ends of the spectrum are industrial design and R\&D services. Designers tend to yield both types of control rights to clients, perhaps reflecting the low bargaining power of these small firms and the strategic importance of new product designs to clients. R\&D service providers, in contrast, although contributing to clients' R\&D activities, are most likely to

\footnotetext{
${ }^{8}$ Industrial design refers here to services contributing to aesthetic, ergonomic, and functional aspects of new products. These services are to be distinguished from more technologically-oriented engineering design and less
} 
retain both types of control rights. Many R\&D service firms develop proprietary service technologies, to which they retain rights after service projects are completed.

We consider two measures of innovation output. These are binary indicators for firms that have launched new or significantly improved services. Survey questions asked whether the firm had introduced significantly improved services in the previous three years and whether it had introduced completely new services during the same time period (new to the firm itself, not necessarily to the market). These questions parallel those used in European Community Innovation Surveys, designed by the Eurostat and found to contain relevant information in a voluminous stream of research (see e.g., Mairesse \& Mohnen, 2002; Veugelers \& Cassiman, 1999). About half of the firms surveyed here had launched new or improved services, more firms making improvements than launching new services, as one would expect. Management consultancies report particularly high rates of innovation. In contrast, electrical engineering firms appear less active in developing new services. These data on new or significantly improved services will be used as dependent variables to test hypotheses 4 and 5 .

To provide an idea of what kinds of service innovations the above variables may be capturing, the following examples for new services and service improvements were mentioned in interviews with business service executives. The CEO of a management consulting firm described a novel method of building work teams in organizations, associated with a special display board that visualizes and organizes the process. This firm had obtained a patent for the board. It licensed this service innovation and the boards to other management consulting firms. A shipbuilding engineering firm executive disclosed that the firm was in the process of developing a new service concept based on a life-cycle model for building large ships. The new 
service would optimize the construction process and materials use from the very beginning through the various stages of the ship's life cycle all the way to its eventual disassembly and recycling of parts. A service improvement mentioned by another management consulting executive concerned applying an existing team-building process in a networked context. In other words, the firm developed a modified team-building service concept for clients who operate in multiple locations connected through an intranet communication network. Indeed, service improvements in many of the firms interviewed involved implementing information and communication technologies in the delivery of existing services.

Insert table 1 about here

Hypotheses 1-3 concern the effects of service firms' indispensability, innovation capabilities, and bargaining power on the likelihood of retaining control rights to intellectual assets. To develop proxies for the indispensability of service firms, we use variables that characterize business service firms' typical interactions with clients in projects. The underlying survey questions were developed based on interviews with CEOs. Most often, individual consultants from service firms are hired to join clients' projects as outside experts. Then, consultants essentially work in client-led projects as supplementary human resources. In some cases, however, business service firms carry out projects for the client independently, that is, in relatively infrequent interaction with the client. The service provider can also provide project planning and design. The survey questionnaire asked respondents to indicate how often (never, sometimes, often, or always) their firm operates in these roles. It is argued that these aspects of the service relationship provide useful information regarding the parties' relative contributions to service projects, in other words, their indispensability. Firms operating independently or providing project design are more indispensable than those operating as outside experts. 
Explanatory variables related to firms' innovation capabilities include measures for firms' skill levels and service development activities. KIBS firms' success in innovation and business operations depends to a very large degree on the skills and competencies of their employees and teams. Higher education is a critical source of skills for KIBS industries (see table 1). In an average firm, one third of KIBS employees have higher education (college or university) degrees, the median being $25 \%$, and almost three percent of employees in the firms surveyed have post graduate (licentiate or Ph.D.) degrees. Research and service development activities by KIBS firms are also common and entail quite significant investments. $60 \%$ of firms report having invested in the development of their services, and $20 \%$ of firms have a permanent development team or department. The mean of service development expenditures is $6.3 \%$ of sales. ${ }^{9}$

Bargaining power of the sampled service firms is proxied by a set of firm characteristics that measure firms' reputation and position in the industry. These include firm size, profitability, ownership structure, export activity, and age. These variables are also included as control variables in explaining innovation outcomes.

\section{Empirical Analyses}

\subsection{Empirical variables and models}

The empirical analyses in this section, first, examine the determinants of control rights allocation between service firms and their clients and, second, the characteristics of innovating business service firms. For the latter analyses, we begin by assessing the endogeneity of control rights

\footnotetext{
${ }^{9}$ Excluding three firms with $R \& D$ expenditures greater than or equal to sales yields mean $R \& D$ expenditures per sales of $2.9 \%$.
} 
allocation with respect to innovation output and then proceed to estimate a conditional maximum likelihood system of equations to account for that. Table 2 summarizes the variables used in the estimations for the final sample of 145 firms Tables A1 and A2 in the appendix display these estimation variables' means, standard deviations, and correlations.

Table 2 about here

Equation 1 specifies the model for estimating the determinants of control rights division between the business service firm and its key clients. The alternative dependent variables include ordinal measures for how often the firm's key clients obtain the rights to control intellectual assets created in joint projects (output control rights to client), how often the key clients specify exclusivity arrangements preventing the firm from serving the client's competitors (partial exclusivity), and the sum of these two variables (control rights).

\section{Equation 1 CONTROL RIGHTS TO CLIENT $=f\left[\delta_{0}+\delta_{1} * \log (\right.$ EMPL $)(-)+\delta_{2} *$ GROUP $(-)$ $+\delta_{3} *$ EXPORTS $(-)+\delta_{4} *$ PROFITABILITY $(-)+\delta_{5} *$ AGE $(-)$ $+\delta_{6} *$ HIGHER EDUCATION $(-)+\delta_{7} *$ POSTGRAD EDUCATION (-)$$
+\delta_{8} * \text { R\&D DEPARTMENT }(-)+\delta_{9} * \text { R\&D INVESTMENTS (-) }
$$$$
+\delta_{10} * \text { PROJECT DESIGN }(-)+\delta_{11} * \text { INDEPENDENT (-) }
$$$$
\left.+\delta_{12} * \text { QUALITY SYSTEM }(+)+\delta_{13 \ldots 17} * \text { Industry dummies }+v_{1}\right]
$$

Explanatory variables in equation 1 include firm size, group structure, exports, profitability, and firm age, all of which signal the firm's established position and reputation in the industry and thus improve its chances of retaining control rights through bargaining power. Their expected sign is thus negative (per hypothesis 3 ). Size and profitability are correlated with market power in mainstream economic theories of industrial organization: larger firms have greater market shares that directly imply market power, and the ability to price above marginal cost reflects market power and translates into higher profits. Absence of liquidity constraints may also improve a firm's bargaining position. Moreover, as firms in most areas of knowledge-based 
business services depend largely on their reputations to obtain new clients, a good reputation implies bargaining power. Newly founded business service providers are less likely to have built solid reputations than their more established counterparts, so we assume that age is associated with bargaining power with clients. The extent to which these proxies of bargaining power are significant explanatory variables measures the departure from theoretically optimal allocation based on relative capabilities to innovate and invest in the project.

The contributions made by service firms in client projects may influence their controlrights outcomes. Firms operating independently or providing project design are assumed to be relatively indispensable with respect to project outcomes and thus more likely to retain control rights (per hypothesis 1). Knowledge creation activities are also expected to improve the firm's likelihood of retaining control rights, but for a conceptually different reason. Highly skilled and R\&D-active firms are expected to be more innovative in client relationships, hence their investments may be more critical for the success of the relationship than those of their clients. Highly innovative service firms should thus be made residual claimants (hypothesis 2).

The second empirical model (equation 2) specifies firms' innovation output as a function of their general and structural characteristics, allocation of control rights to clients in contracts, and knowledge creation activities. The expected signs of coefficients are in parentheses.

\section{Equation 2 INNOVATION OUTPUT $=f\left(\beta_{0}+\beta_{1} * \log (\right.$ EMPL $)(+)+\beta_{2} *$ GROUP $(+)$$$
+\beta_{3} * \text { EXPORTS }(+)+\beta_{4} * \text { PROFITABILITY }(+)
$$$$
+\beta_{5} * \text { R\&D DEPARTMENT }(+)+\beta_{6} * \text { R\&D INTENSITY }(+)
$$$$
+\beta_{7} * \text { HIGHER EDUCATION }(+)+\beta_{8} * \text { POSTGRAD EDUCATION }(+)
$$$$
\left.+\alpha * \text { CONTROL RIGHTS TO CLIENT }(-)+\beta_{9, \ldots 13} * \text { Industry dummies }+\mathrm{u}_{2}\right)
$$

There are two innovation output measures: a dummy for firms that significantly improved existing services (IMPROVEMENT) and a dummy for firms that launched new services in the markets in the previous three years (NEW SERVICE). Improvements are arguably more 
incremental service developments than are new service introductions, which require a successful departure from existing service activities and competencies.

Control variables include firm size, which correlates positively with the probability of innovation if there are increasing returns to scale in innovation activities. We use the logarithm of the number of employees to reduce skewness. Members of domestic or international business groups may benefit from knowledge flows from the headquarters' R\&D function, hence the expected sign for group is positive. ${ }^{10}$ Operating in export markets is expected to provide incentives to create new and innovative services, as in existing studies of manufacturing industries. Profitability of the firm may also influence its ability to engage in innovation activities. Finally, knowledge creation investments in the form of investing in service development (R\&D department, R\&D intensity) or hiring skilled employees (higher and post graduate education) are expected to improve the likelihood of successful innovation. However, extant literature suggests that in service firms, R\&D activities tend to be less prominent in the innovation process, and organization of innovation is "ad hoc" (Sundbo, 1997). This would mean that investments in formal service development are not important for innovation success. Empirical tests will assess this conjecture.

The explanatory variables of interest in equation 2 include the indicators for control rights allocation in client relationships. Hypotheses 4 and 5 implied that relationships where clients control the output or supply create weaker incentives to innovate for the service supplier,

\footnotetext{
${ }^{10}$ This is likely to be a significant phenomenon particularly in internationally operating advertising and management consulting companies, where group structure is prevalent and knowledge creation can partly be centralized to a shared R\&D facility. For example, strategy consultancies McKinsey and Boston Consulting Group each have inhouse research institutes that deliver generally applicable information and tools to their consultants. As a result, local subsidiaries of these kinds of global consulting firms benefit from knowledge flows from the headquarters. However, most of the (local) companies in the sample used here do not have permanent in-house R\&D teams or facilities.
} 
because the possibilities to use the results repeatedly and cumulatively are constrained. The expected coefficient is thus negative. We rely on the combined Control rights variable (the sum of Output control rights to client and Partial exclusivity), which ranges from 0 to 6 . The justification for this is that the two forms of contractual arrangements are rather strongly correlated and conceptually assumed to measure the same underlying concept: the degree to which clients can control the service firm's use of its intellectual assets. While the statistical scale of the combined variable is still ordinal, its range of variation is more extensive than in the case of the original survey variables.

Control rights are expected to be endogenous in the model for innovation output. This is the case if the control rights variable is correlated with the error term in equation 2 . This can be tested and accounted for with an instrumental variable approach. The challenge is to find a valid instrument. Particularly in a cross-sectional setup, this is often tricky. We carry out the instrumental variable estimation with the following two instruments: quality system adoption and project design (planning) role.

Quality system adoption is assumed to proxy for a strategy of customizing services, which is conceptually and empirically associated with control right allocation but not with innovation activities. Quality system is a binary variable for whether the firm has implemented such a system to improve the consistency of its service operations and to signal high quality to potential clients. This variable is expected to be positively related to yielding control rights to clients, because it is associated with service firms whose strategic focus is on customization rather than services that are intended for replication and thus benefit from retention of control rights. Providers of customized services are more likely to need the high quality signal created by quality system adoption than are providers of standardized or packaged services. Providers of 
customized services are also less dependent on the rights to control their output; in fact, they are often transferred to clients with the service project output. Unfortunately, the dataset contains no direct indicator of service customization. Therefore, quality systems are assumed to proxy customization and expected to be negatively associated with yielding control rights to clients.

The second instrument, project design, is based on a survey question of how regularly the service firm designs projects for their key clients. This question is on a four-point scale, ranging from 0 (never) to 3 (always). We assume that firms that design new projects for their clients are more indispensable in these projects, and, therefore, more likely to retain control rights in their client relationships. This is analogous to the measure used by Lerner and Merges (1998: 138) to distinguish early and late stage research. Lerner and Merges argue that control rights in very early discovery stage research projects should be allocated to the R\&D firm because of the marginal impact of their research effort on the value of the project outcome is greater. Similarly, in the early stages of service projects, the service provider has a greater opportunity to influence the project outcome, and, hence, is more indispensable.

Regarding the empirical validity of these instrumental variables, neither variable is statistically different from zero when included in equation 2 estimating service innovation, although this test is by no means sufficient to establish validity. The more important consideration is conceptual. We are not aware of conceptual arguments suggesting that quality system adoption (or service customization that it proxies) or providing early-stage project design services for clients directly influence innovation output. First, there is a priori no reason to expect customized service providers (say, Bain \& Company in management consulting) to be more or less innovative in terms of improving or renewing their services than more standardized service providers (say, Accenture in the same industry). Both types of firms should benefit from 
improved or new services, although the types of innovations they generate are probably different. Second, there is no reason to think that early-stage interventions in client projects lead to more or less service innovation than late-stage interventions. As an example here, one could think of an industrial design firm that contributes to the client's new product development project at a stage where technical product specifications are yet to be defined, rather than providing product designs according to the set specifications. Both types of service suppliers should benefit from improved processes or new service concepts.

These variables should thus in principle be valid instruments in the estimation of control rights allocation. However, project design services may be correlated with innovation capabilities, because they are likely to be provided by larger and more established firms. Project design services are associated with greater uncertainty about service quality compared to projects where clients lead and closely monitor service delivery. Large and established firms have greater reputations than small and young firms, but they are also more likely to have innovation capabilities. Controlling for other firm characteristics is therefore important. However, for firms of similar size and reputation, those providing early-stage project services should not be any more likely to innovate than those providing later-stage project services. Other firm characteristics (firm size, age, profitability, employee skills, R\&D intensity, export capacity, and group affiliation) are also expected to influence control rights outcomes, but they may affect innovation output directly, too, and therefore would not be valid as instruments.

\subsection{Estimation methods}

We first estimate the determinants of the ordinal dependent variables related to equation 1 with ordered probit maximum likelihood method. We then proceed to test for the endogeneity of control rights in equation 2 and develop an instrumental variable approach to account for this 
issue. According to Wooldridge (2002) and Rivers and Vuong (1988), endogeneity of a continuous variable in a probit model can easily be tested with a two-stage approach. If the error terms in equations 1 and 2 are correlated, then the control rights variable is endogenous. This can be assessed by first estimating equation 1 and then inserting the residuals as an additional explanatory variable into equation 2 . Statistical significance of the residuals would indicate endogeneity.

Endogeneity in a model with a binary dependent variable can be corrected with two-stage methods (Maddala, 1983) or conditional maximum likelihood. The advantage of the latter method is, first, higher efficiency and, second, that one can obtain direct estimates of $\alpha$ (the coefficient of control rights in equation 2) and the $\beta_{0 \ldots 13}$ parameters. Two-stage methods only yield these parameters up to a scale. Wooldridge (2002) derives the likelihood function under the joint distribution of the dependent variables in equations 1 and 2 (control rights and innovation). In addition to the parameters of interest in equations 1 and 2, this method generates estimates for the correlation $\rho$ between the error terms $(u, v)$ and variance $\tau^{2}$ of $v$. If these parameters are relevant, accounting for them increases the accuracy of the estimates. This procedure was programmed and estimated with RATS v. 4.30. We sketch the conditional likelihood estimation approach below by rewriting empirical equations 1 and 2 (cf. Wooldridge 2005: 476) as:

$$
\begin{aligned}
& y_{1}=\mathbf{z}_{1} \boldsymbol{\delta}_{1}+\mathbf{z}_{2} \boldsymbol{\delta}_{2}+v_{1}=\mathbf{z} \boldsymbol{\delta}+v_{1} \\
& y_{2}{ }^{*}=\mathbf{z}_{1} \boldsymbol{\beta}+\alpha y_{1}+u_{2} ; \quad y_{2}=1\left[y_{2}{ }^{*}>0\right]
\end{aligned}
$$

Rewrite the second equation when the error terms are correlated as:

$$
\begin{aligned}
& y_{2}{ }^{*}=\mathbf{z}_{1} \boldsymbol{\beta}+\alpha y_{1}+\theta v_{1}+e_{2} ; y_{2}=1\left[y_{2}{ }^{*}>0\right] \\
& \text { where } e_{2} \mid \mathbf{z}, y_{1}, v_{1} \sim \operatorname{Normal}\left(0,1-\rho^{2}\right) \text { and } \theta=\rho / \tau
\end{aligned}
$$

To derive the joint distribution of $\left(y_{1}, y_{2}\right)$, Wooldridge exploits that: 


$$
f\left(y_{1}, y_{2} \mid \mathbf{z}\right)=f\left(y_{2} \mid y_{1}, \mathbf{z}\right) f\left(y_{1} \mid \mathbf{z}\right)
$$

and the conditional density of $y_{2}$ given $\left(y_{1}, \mathbf{z}\right)$, which is:

$\mathrm{P}\left(y_{2}=1 \mid y_{1}, \mathbf{z}\right)=\Phi\left[\left(\mathbf{z}_{1} \boldsymbol{\beta}+\alpha y_{1}+(\rho / \tau)\left(y_{1}-\mathbf{z} \boldsymbol{\delta}\right)\right) /\left(1-\rho^{2}\right)^{1 / 2}\right]=\Phi[\mathrm{w}]$

The log likelihood function to be maximized in the estimation is then obtained by taking the natural logarithm of:

$$
f\left(y_{1}, y_{2} \mid \mathbf{z}\right)=\Phi(\mathrm{w})^{\mathrm{y} 2}\{1-\Phi(\mathrm{w})\}^{1-\mathrm{y} 2}(1 / \tau) \varphi\left[\left(y_{1}-\mathbf{z} \boldsymbol{\delta}\right) / \tau\right]
$$

\subsection{Estimation results}

We first estimate the determinants of control rights allocation. Table 3 presents the results for equation 1, with three different ordinal dependent variables. The estimation method is ordinal probit maximum likelihood. We include two measures to capture the role of the service provider in clients' projects: project design and independent. Both are negatively associated with control rights signed away to clients, but only project design is statistically significantly so. This variable is strongly associated with output control rights and the combined control right variable - supporting the first hypothesis - but it only has a weak negative effect on the likelihood of partial exclusivity arrangements.

Regarding the innovation capability hypothesis (H2), having an institutionalized R\&D department and providing $R \& D$ services are negatively and significantly associated with yielding the rights to control intellectual output to clients, lending support for hypothesis 2 . However, partial exclusivity arrangements are not affected by these innovation capabilities.

Finally, bargaining power measured by profitability significantly explains output control allocation and the combined control variable, and firm age is significant in these models as well. Additionally, exporting service firms are significantly less likely to agree to partial exclusivity. 
These coefficients support hypothesis 3: bargaining power helps service firms to retain control rights. Firm size measured by the logarithm of employees is positively related to yielding control rights to clients, contrary to expectations, although the coefficient is marginally significant only in the last specification. If profitability and age are removed from the specification, the coefficient of firm size becomes much smaller and highly insignificant. These results suggest that bargaining power based on financial performance and established position in the industry are more relevant than sheer size.

Table 3

These estimation results broadly align with hypotheses 1,2 , and 3 in terms of coefficient signs, but their statistical significance varies with the dependent variable used. Nevertheless, all but two coefficients have the same signs in the three specifications, and these two coefficients are practically zero (export dummy in the first model and R\&D department in the second model). Additionally, all models in table 3 include the quality system variable that was expected to be positively related to yielding control rights to clients. This variable is positively and significantly associated with the combined control rights variable, and weakly significant in the partial exclusivity specification.

Inserting the residuals from the estimation model for combined control rights into probit specifications for new services and service improvement suggests that control rights are probably endogenous. The coefficient of the residuals obtains a statistical significance level of $93 \%$ in both models (see table A3 in the appendix). Therefore, we next estimate the effect of control rights on innovation using the conditional maximum likelihood approach. Table 4 reports these results. Results from single equation probit and OLS models are used as starting values.

Table 4 about here 
The predicted value for control rights obtains a negative and statistically significant coefficient in the conditional likelihood models for both service improvements and new service introductions, aligned with hypothesis 4 . The results are also in line with the fifth hypothesis: The effect of predicted control rights is slightly larger in explaining new services than in explaining service improvements. These results are also qualitatively similar to the earlier singleequation results for control rights: profitability, firm age, and quality system are statistically significantly associated with control rights allocation. In contrast, the project design instrument works well only in the conditional likelihood model for new services. Also, variables measuring innovation capability remain statistically insignificant in explaining control rights allocation here.

Regarding the control variables in the innovation equation, few variables are significant in explaining both service improvements and new service introductions. Business group structure and export intensity significantly explain service improvement, while higher education of employees is important for new service introduction.

The age variable was not included as an explanatory variable of innovation output, as it is not a standard explanatory factor behind innovation. However, Sorensen and Stuart (2000) suggest that there is a link between firm age and innovativeness. In supplementary analyses the age variable was therefore included in both equations 1 and 2 . This had no effect on the results concerning the impact of control rights allocation on service improvements. The coefficient of age in explaining new services or service improvements was not significantly different from zero.

As another robustness analysis, we experimented with an additional service strategy variable in order to make sure that firms' service strategy is not causing both control rights 
allocation and innovation. Löwendahl (1997) has argued that for professional services, the choice between individual or organizational control of key resources is central in determining strategic orientation. In earlier studies (Leiponen, 2006a; 2006b), a variable describing business service firms' strategic focus on individual control of resources was found to influence their strategies regarding control rights allocation and innovation. This dimension was approximated in the current dataset by the survey question "how often can your firm's cooperation with key clients be described as participating in client projects as outside experts." In the Aghion and Tirole (1994) framework, this survey question can be seen to reflect a situation where the service provider does not take major responsibility regarding the project outcome. This "outside expert" variable was found to weakly and positively influence control rights allocation, but it had no effect on innovation outcomes, the instrumental variables, or the main results concerning the relationship between control rights and innovation. ${ }^{11}$

In the nonresponse analysis it was found that the sample may be slightly biased toward large firms. To see if this had an effect on the results, we formed an interaction term for the natural logarithm of employees and the combined control rights indicator. The interaction term was not significantly different from zero, suggesting that the main result concerning the effect of control rights allocation on innovation outcomes is not different for small and large firms.

Considering that there are significant differences across industries with respect to both control rights allocation and innovation, we performed some final robustness checks by interacting the key explanatory variables with industry dummies to allow for their effects to vary across industries. We focus on the consistency of the effects of the instrumental variables project

\footnotetext{
${ }^{11}$ All of these supplementary results are available from the author on request.
} 
design and quality system on control rights, and on the consistency of the effect of the control rights variable on innovation outcomes.

Regarding the instrumental variables, we found that in linear (OLS) models of control rights, the project design variable had a negative coefficient in five of the six industries. The magnitudes of these negative coefficients varied between -0.340 and -0.551 . Only in the electrical engineering industry did we obtain a positive coefficient of 0.265 . This industry may thus be an outlier. Similarly, the quality system variable obtained positive coefficients from five out of six industries, and the negative coefficient for the machine and process engineering was not very significant. We also estimated with these industry-specific coefficients for the instruments in the conditional likelihood instrumental variable model, but they had no effect on the main results in the innovation equation.

We also allowed the effect of control rights on innovation outcomes vary across industries. It was difficult to obtain robust coefficients for industrial design and R\&D services, the two smallest subsamples, so we estimated one coefficient for the whole sample and separate coefficients for firms in advertising, engineering, or management consulting industries. In the conditional likelihood models of innovation output, all industry-specific coefficients on control rights were negative. Thus, while there is some variation across industries in the strength of the effect, the relationship between control rights and innovation is negative in all industries.

The performance of the second instrumental variable (project design) was not completely satisfactory in the analyses. It is significant only at the $90 \%$ level in the model for service improvements. However, this variable does appear to work well in the model for new services. Moreover, it is not significantly correlated with the residuals in either equation (its correlation coefficient is $-5.5 \%$ with service improvement residuals and $-9.8 \%$ with new service introduction 
residuals), which increases our confidence in its performance. Quality system variable, on the other hand, worked slightly better in the model for service improvements than in the model for new services. Thus, although each instrument has its shortcomings, taken together, we have somewhat greater confidence that these two variables are able to identify exogenous variation in control rights in the conditional maximum likelihood models.

Finally, the $\rho$ parameter in the conditional maximum likelihood estimation suggests that the residuals (error terms) in the two equations are strongly correlated. This means that there are omitted variables or unobserved firm heterogeneity that impact both control right allocation and innovation outcomes. We probably could account for such unobserved characteristics only with panel data or some type of a natural experiment. The $\rho$ parameter thus reminds us of the limitations of the current research design: the cross-sectional models are unlikely to be able to account for all factors that affect control rights and innovation. Only to the degree that the instrumental variables are able to identify exogenous variation in control rights, we have correctly estimated the effect of control rights on innovation outcomes.

\section{Discussion and Concluding Remarks}

This paper examines the determinants and effects of contractual arrangements in business-tobusiness service relationships. The empirical context of study is knowledge-intensive business services. The study focuses on contractual features concerning the control and use of intellectual assets in client relationships. These are found to have significant effects on business service firms' innovation outcomes. Theoretical work in economics has focused on performance contracts as a source of incentives in economic relationships, but these kinds of contracts may be impractical in many situations due to measurement problems and other sources of 
incompleteness. In contrast, this study argues that control rights to service supply or output are significantly associated with incentives to innovate and could be strategically used to generate incentives for knowledge suppliers or cooperation partners.

Cross-sectional instrumental variable estimation results indicate that service firms who operate under tight client control of service supply or output are significantly less likely to introduce new services or improve existing services. Marginal effects from single-equation models suggest that the probability of introducing new services in firms that always yield control rights to their clients is $20-30 \%$ lower than in firms that never or only occasionally yield control rights. Contractual arrangements can thus have dynamic ramifications through service innovation.

The results also show that contractual arrangements depend on the service firm's bargaining power, $R \& D$ orientation, and role in client projects. First, bargaining power measured by firm age and profitability increases the likelihood of retaining control rights. These results may reflect suboptimal division of control rights. Relative abilities to invest in noncontractible activities, not bargaining power, should socially optimally be the basis of control right allocation. According to marginal effect estimates from single-equation probit models, misallocation of control rights because of bargaining power differences implies up to $23 \%$ smaller probability of service innovation. In terms of our measures of bargaining power, the marginal effect estimates suggest that firms whose profitability is one standard deviation lower than the mean are $14 \%$ less likely to retain rights to service output and $2 \%$ less likely to avoid exclusivity restrictions. The social welfare reduction due to control right misallocation is probably smaller than that implied by the above numbers, however, because when the service 
firm loses the rights and the associated incentive to innovate, the client firm obtains them and, as a result, is more likely to innovate than without the rights.

Second, the noncontractible investments that should optimally be the basis for control right allocation were proxied by $R \& D$ activities and project roles. The presence of an $R \& D$ unit and the industry segment of $R \& D$ services, not $R \& D$ investments or research skill intensity per se, turn out to explain the division of control rights, but not very consistently. We thus have limited evidence for the hypothesis that the ability to innovate is driving control right allocation, although this result may be specific to the sample of business service firms used here. ${ }^{12}$ Regarding project roles, service firms that often or always take on project responsibility in terms of designing the clients' projects are significantly more likely to retain control rights. This result is aligned with the property-rights theoretic prediction that the party who is more "indispensable" in terms of project outcome should be the residual claimant.

Quality system adoption may also proxy for a different aspect of the services offered: firms that find the signaling associated with quality systems valuable for their competitiveness are likely to provide customized services, where clients usually obtain control rights, particularly exclusivity. Quality system adoption and project design role were used as instrumental variables in the conditional likelihood models. In each conditional likelihood model, at least one of these variables is significant at the $95 \%$ level, and neither variable is significantly correlated with the residuals of the innovation outcome models. At least superficially, thus, it appears that we are able to identify the variation in control rights allocation that is exogeneous to innovation outcomes. In principle, however, such firm-specific instruments are not ideal. Their complete

\footnotetext{
${ }^{12}$ With data of biotechnology firms, Lerner and Merges (1998) found that if firms were strong both in terms of their financial and patent positions (an interaction effect), they were more likely to retain control rights.
} 
exogeneity with respect to innovation output cannot be ascertained, and it is possible that we have not fully accounted for endogeneity. Thus, the most cautious interpretation of the results is that innovative service firms tend to retain control rights to their intellectual assets, but the direction of causality is not firmly established - it may run in both directions. Only to the extent that the instruments identify exogenous changes in control rights do the conditional likelihood estimations express the statistical significance and magnitude of the causality from control rights to innovation output. More conclusive answers can probably only be obtained with longitudinal or transaction-level data from multiple service firms.

The novel management implication of these results for client firms is that incentives for noncontractible investments should be considered when long-term contracts with knowledge suppliers are crafted. In long-term service supply relationships, the client may sometimes benefit more from an accelerated pace of knowledge creation by the service supplier than from tight control of existing intellectual assets. How to balance these factors depends on the relative innovativeness of the partners.

These results on the external control of resources resonate with those by Bakos and Brynjolfsson (1993), who argue in a study of information technology supplier relations that client firms may benefit from reducing their own bargaining power by limiting the number of suppliers. Having fewer suppliers gives each supplier stronger incentives to invest in noncontractible activities such as innovation and quality improvement. More generally, optimizing long-term relationships with knowledge-intensive and innovative suppliers requires consideration of suppliers' incentives to learn and innovate. Control rights to intellectual assets can be one way to boost these incentives. 
To conclude, this study suggests that there are significant interactions between organizational arrangements in supplier relationships and noncontractible activities such as service innovation and improvement. The results in this paper align with those of Lerner and Merges (1998) that control rights are not only allocated based on the relative abilities of the parties to innovate or contribute to the project, but also based on their bargaining positions. Furthermore, the most novel results in this paper show that control rights allocation is significantly associated with innovation outcomes. While tightly controlling intellectual assets may often be strategically important for business service firms' clients, the clients should balance this strategic goal against the benefits from a more optimal allocation of control rights in terms of the incentives to innovate created for their repeated service suppliers. 
Table 1 Descriptive statistics by industry

\begin{tabular}{|c|c|c|c|c|c|c|c|c|c|}
\hline & $\begin{array}{l}\text { All } \\
\text { firms }\end{array}$ & $\begin{array}{l}\text { Industrial } \\
\text { Design }\end{array}$ & $\begin{array}{l}\text { Adver- } \\
\text { tising }\end{array}$ & $\begin{array}{l}\text { Management } \\
\text { consulting }\end{array}$ & $\begin{array}{c}\text { R\&D } \\
\text { services }\end{array}$ & $\begin{array}{c}\text { Machine, } \\
\text { process } \\
\text { engineering }\end{array}$ & $\begin{array}{c}\text { Electrical } \\
\text { engineering }\end{array}$ & $\begin{array}{c}\text { Engineering } \\
\text { services } \\
\text { combined }\end{array}$ & $\begin{array}{l}\text { Engineering } \\
\text { services in Finnish } \\
\text { CIS (1996) }\end{array}$ \\
\hline Sales MFIM (1999) & 28.936 & 2.81 & 45.37 & 37.78 & 16.39 & 32.69 & 9.82 & 23.32 & 60.42 \\
\hline Employees (1999) & 44.77 & 6.70 & 37.22 & 55.00 & 36.82 & 77.33 & 23.62 & 54.81 & 56.85 \\
\hline Export share (1999) & 0.125 & 0.018 & 0.011 & 0.083 & 0.338 & 0.229 & 0.118 & 0.182 & 0.273 \\
\hline Sales/employee (MFIM) & 0.692 & 0.324 & 0.987 & 0.996 & 0.583 & 0.534 & 0.408 & 0.481 & 1.088 \\
\hline Firm age (1999) & 18.01 & 13.50 & 17.28 & 20.50 & 23.41 & 17.14 & 16.00 & 16.66 & n.a. \\
\hline Business group & 0.414 & 0.200 & 0.500 & 0.500 & 0.294 & 0.444 & 0.269 & 0.371 & n.a. \\
\hline Service improvements & 0.566 & 0.200 & 0.667 & 0.813 & 0.588 & 0.528 & 0.385 & 0.468 & n.a. \\
\hline New service introductions & 0.483 & 0.600 & 0.472 & 0.625 & 0.588 & 0.472 & 0.192 & 0.354 & 0.385 \\
\hline R\&D investments/sales & 0.063 & 0.025 & 0.014 & 0.028 & 0.385 & 0.022 & 0.022 & 0.022 & 0.027 \\
\hline $\mathrm{R} \& \mathrm{D}$ department or team & 0.200 & 0.200 & 0.139 & 0.188 & 0.294 & 0.194 & 0.192 & 0.193 & n.a. \\
\hline $\begin{array}{l}\text { Higher education degrees } \\
\text { (\% of employees) }\end{array}$ & 32.76 & 65.90 & 25.69 & 64.97 & 42.29 & 21.53 & 23.35 & 22.29 & 55.74 \\
\hline $\begin{array}{l}\text { Post graduate education ( } \% \text { of } \\
\text { employees) }\end{array}$ & 2.46 & 5.00 & 1.03 & 2.25 & 11.82 & 0.64 & 0.33 & 0.52 & n.a. \\
\hline Independent service provision & 1.83 & 2.22 & 1.74 & 1.44 & 1.94 & 1.92 & 1.83 & 1.88 & n.a. \\
\hline Project design & 1.37 & 1.20 & 1.53 & 1.50 & 1.41 & 1.39 & 1.12 & 1.27 & n.a. \\
\hline Quality system & 0.41 & 0.20 & 0.09 & 0.60 & 0.59 & 0.31 & 0.56 & 0.64 & n.a. \\
\hline Output control rights to client & 2.21 & 2.80 & 2.43 & 2.06 & 1.71 & 2.21 & 2.08 & 2.15 & n.a. \\
\hline Partial exclusivity & 1.28 & 2.50 & 1.81 & 1.84 & 1.12 & 2.03 & 1.75 & 1.92 & n.a. \\
\hline Response rate $(\%)$ & 42 & 41 & 41 & 35 & 48 & 51 & 40 & 46 & $\begin{array}{l}71 \text { (all service } \\
\text { industries) }\end{array}$ \\
\hline $\mathrm{N}$ & 145 & 10 & 39 & 16 & 17 & 35 & 24 & 59 & 39 \\
\hline
\end{tabular}

n.a. = not available

Output control rights to client, partial exclusivity, project design, and independent service provision have four-point scales ranging between 0-3 (never, sometimes, often, always). 
Table 2 Estimation variables

\begin{tabular}{|c|c|c|c|c|}
\hline & Variable & Description & Role in equation 1 & Role in equation 2 \\
\hline \multirow{2}{*}{$\begin{array}{l}\text { Innovation } \\
\text { outcomes }\end{array}$} & Improvement & Significant service improvements $(0 / 1)$ & Not included & Dependent variable 1 \\
\hline & New service & New service introductions $(0 / 1)$ & Not included & Dependent variable 2 \\
\hline \multirow{7}{*}{$\begin{array}{l}\text { Basic firm } \\
\text { Characteristics }\end{array}$} & Log(employees) & Log(number of employees) 1999 & Proxy for bargaining power (H3) & Control variable \\
\hline & Export intensity & Exports per sales 1999 & Not included & Control variable \\
\hline & Exports $>0$ & Any exports in $1999(0 / 1)$ & Proxy for bargaining power (H3) & Not included \\
\hline & Business group & Subsidiary or member in a business group & Proxy for bargaining power (H3) & Control variable \\
\hline & Profitability & Sales/employee 1999 & Proxy for bargaining power (H3) & Control variable \\
\hline & Age & Age of the firm 1999 (years) & Proxy for bargaining power $(\mathrm{H} 3)$ & Not included \\
\hline & Quality system & Firm has adopted a quality system $(0 / 1)$ & Instrumental variable & Not included \\
\hline \multirow{3}{*}{ Control rights } & $\begin{array}{l}\text { Output control } \\
\text { rights to client }\end{array}$ & $\begin{array}{l}\text { "How often does your key or most important client } \\
\text { obtain the control rights to intellectual output: } \\
\text { never, sometimes, often, or always?" (0-3) }\end{array}$ & Dependent variable 1 & Not included \\
\hline & Partial exclusivity & $\begin{array}{l}\text { "How often do you sign an agreement which } \\
\text { specifies that you will not provide services to your } \\
\text { key client's competitors: never, sometimes, often, } \\
\text { or always?" }(0-3)\end{array}$ & Dependent variable 2 & Not included \\
\hline & Control rights & $\begin{array}{l}\text { The sum of output control rights to client and } \\
\text { partial exclusivity }(0-6)\end{array}$ & Dependent variable 3 & $\begin{array}{l}\text { Key explanatory } \\
\text { variable }(\mathrm{H} 4, \mathrm{H} 5)\end{array}$ \\
\hline \multirow{5}{*}{$\begin{array}{l}\text { Knowledge } \\
\text { creation }\end{array}$} & R\&D department & $\begin{array}{l}\text { The firm has a permanent service development } \\
\text { team or department }(0 / 1)\end{array}$ & $\begin{array}{l}\text { Proxy for innovation capability } \\
\text { (H2) }\end{array}$ & Control variable \\
\hline & R\&D intensity & Service development investments/sales (\%) & Not included & Control variable \\
\hline & $\mathrm{R} \& \mathrm{D}$ investments $>0$ & Any R\&D investments in $1999(0 / 1)$ & $\begin{array}{l}\text { Proxy for innovation capability } \\
\text { (H2) }\end{array}$ & Not included \\
\hline & Higher education & Share of employees with higher education (\%) & $\begin{array}{l}\text { Proxy for innovation capability } \\
\text { (H2) }\end{array}$ & Control variable \\
\hline & Post grad education & $\begin{array}{l}\text { Share of employees with post graduate degrees } \\
(\%)\end{array}$ & $\begin{array}{l}\text { Proxy for innovation capability } \\
(\mathrm{H} 2)\end{array}$ & Control variable \\
\hline \multirow{2}{*}{$\begin{array}{l}\text { Role in service } \\
\text { projects }\end{array}$} & Independent & $\begin{array}{l}\text { Service projects are carried out independently } \\
\text { from client (0-3: never, sometimes, often, always) }\end{array}$ & Proxy for indispensability (H3) & Not included \\
\hline & Project design & Service provider designs projects for clients $(0-3)$ & $\begin{array}{l}\text { Proxy for indispensability (H3); } \\
\text { instrumental variable }\end{array}$ & Not included \\
\hline
\end{tabular}


Table 3 Determinants of control rights allocation

\begin{tabular}{|c|c|c|c|c|c|c|}
\hline \multirow[t]{2}{*}{ Dependent variable } & \multicolumn{2}{|c|}{$\begin{array}{l}\text { OUTPUT CONTROL } \\
\text { RIGHTS TO CLIENT }\end{array}$} & \multicolumn{2}{|c|}{ PARTIAL EXCLUSIVITY } & \multicolumn{2}{|c|}{ CONTROL RIGHTS } \\
\hline & Coeff. & Std.Err. & Coeff. & Std.Err. & Coeff. & Std.Err. \\
\hline Constant & $3.740 * * *$ & 0.629 & $1.351 * *$ & 0.584 & $3.706^{* * *}$ & 0.537 \\
\hline Log(employees) & 0.153 & 0.114 & 0.149 & 0.116 & $0.198 *$ & 0.106 \\
\hline Business group & 0.088 & 0.216 & 0.341 & 0.218 & 0.282 & 0.200 \\
\hline Exports $>0$ & 0.019 & 0.238 & $-0.506 * *$ & 0.241 & -0.325 & 0.220 \\
\hline Profitability & $-0.447 * * *$ & 0.166 & -0.175 & 0.170 & $-0.406 * * *$ & 0.154 \\
\hline Age & $-0.018 * *$ & 0.008 & $-0.014 *$ & 0.008 & $-0.020 * * *$ & 0.007 \\
\hline R\&D department & $-0.534 * *$ & 0.253 & 0.019 & 0.256 & -0.162 & 0.237 \\
\hline$R \& D$ investments $>0$ & -0.162 & 0.218 & -0.021 & 0.217 & -0.110 & 0.201 \\
\hline Higher education & 0.004 & 0.004 & 0.002 & 0.004 & 0.006 & 0.004 \\
\hline Post graduate education & -0.003 & 0.018 & -0.001 & 0.016 & -0.005 & 0.015 \\
\hline Independent & -0.118 & 0.137 & -0.079 & 0.140 & -0.120 & 0.127 \\
\hline Project design & $-0.346 * *$ & 0.144 & -0.096 & 0.141 & $-0.260 * *$ & 0.132 \\
\hline Quality system & 0.301 & 0.238 & $0.409 *$ & 0.238 & $0.439 * *$ & 0.222 \\
\hline Advertising & -0.302 & 0.459 & -0.289 & 0.431 & -0.245 & 0.394 \\
\hline Machine and process engineering & $-1.061 * *$ & 0.492 & -0.257 & 0.451 & -0.564 & 0.415 \\
\hline Electrical engineering & $-1.271 * * *$ & 0.484 & -0.512 & 0.442 & $-0.774 *$ & 0.416 \\
\hline Management consulting & $-1.024 * *$ & 0.496 & -0.478 & 0.477 & $-0.780 *$ & 0.435 \\
\hline R\&D services & $-1.427 * * *$ & 0.517 & -0.358 & 0.471 & $-0.836 *$ & 0.436 \\
\hline \multirow{6}{*}{$\begin{array}{l}\text { Log likelihood } \\
\text { Threshold parameters }\end{array}$} & -147.34 & & -144.636 & & -232.25 & \\
\hline & $\mu(1)$ & $1065 * * *$ & $\mu(1)$ & $\begin{array}{l}1.205 * * \\
*\end{array}$ & $\mu(1)$ & 0010 \\
\hline & & $2.374 * * *$ & & & $\mu(2)$ & 1.695 \\
\hline & & & & & $\mu(3)$ & 2.485 \\
\hline & & & & & $\mu(4)$ & 3.061 \\
\hline & & & & & $\mathrm{Mu}(5)$ & 3.636 \\
\hline
\end{tabular}

Notes: $* * *$ denotes $99 \%$ significance, $* *$ denotes $95 \%$ significance, $*$ denotes $90 \%$ significance levels. 145 observations. In the Partial Exclusivity model, categories 1 and 2 of the original survey variable were combined to improve the prediction power of the model (the estimation with the original variable was not able to distinguish between the two middle categories). Estimated with ordered probit ML. The reference industry is industrial design. 
Table 4 Conditional maximum likelihood estimation of service innovation and control rights using quality system and project design as the instrumental variables

\begin{tabular}{|c|c|c|c|c|c|c|c|c|}
\hline \multirow{3}{*}{$\begin{array}{l}\text { Dependent variable } \\
\text { Variable }\end{array}$} & \multicolumn{4}{|c|}{ Control rights and service improvement } & \multicolumn{4}{|c|}{ Control rights and new service introduction } \\
\hline & \multicolumn{2}{|c|}{ CONTROL RIGHTS } & \multicolumn{2}{|c|}{ IMPROVEMENT } & \multicolumn{2}{|c|}{ CONTROL RIGHTS } & \multicolumn{2}{|c|}{ NEW SERVICE } \\
\hline & Coeff. & Std. error & Coeff. & Std. error & Coeff. & Std. error & Coeff. & Std. error \\
\hline Constant & $5.086 * * *$ & 0.744 & 1.156 & 0.922 & $5.105 *$ & 0.752 & $2.233 * * *$ & 0.732 \\
\hline Log(employees) & $0.244 *$ & 0.140 & 0.265 & 0.121 & $0.269 *$ & 0.147 & $0.203 *$ & 0.109 \\
\hline Business group & 0.409 & 0.297 & $0.718 * * *$ & 0.278 & 0.397 & 0.281 & $0.408 *$ & 0.248 \\
\hline Exports $>0$ & $-0.523 *$ & 0.267 & & & -0.467 & 0.288 & & \\
\hline Export intensity & & & $-0.951 * *$ & 0.438 & & & -0.593 & 0.470 \\
\hline Profitability & $-0.507 * *$ & 0.197 & -0.108 & 0.181 & $-0.517^{* *}$ & 0.160 & -0.287 & 0.216 \\
\hline Age & $-0.024 * *$ & 0.011 & & & $-0.026 * *$ & 0.011 & & \\
\hline Higher education & 0.007 & 0.005 & 0.007 & 0.005 & 0.007 & 0.005 & $0.012 * *$ & 0.006 \\
\hline Post grad education & -0.007 & 0.034 & 0.018 & 0.023 & -0.007 & 0.034 & -0.023 & 0.030 \\
\hline R\&D department & -0.095 & 0.379 & 0.628 & 0.411 & -0.165 & 0.345 & 0.071 & 0.321 \\
\hline $\mathrm{R} \& \mathrm{D}$ investments $>0$ & -0.376 & 0.255 & & & -0.155 & 0.249 & & \\
\hline R\&D intensity & & & 1.227 & 2.786 & & & 0.586 & 1.995 \\
\hline Quality system & $0.631 * *$ & 0.265 & & & $0.580 * *$ & 0.277 & & \\
\hline Project design & -0.203 & 0.139 & & & $-0.347 * *$ & 0.143 & & \\
\hline Independent & -0.123 & 0.148 & & & -0.117 & 0.152 & & \\
\hline Predicted control rights & & & $-0.600 * * *$ & 0.131 & & & $-0.623 * * *$ & 0.127 \\
\hline Advertising & -0.384 & 0.564 & 0.303 & 0.469 & -0.340 & 0.574 & -0.524 & 0.433 \\
\hline $\begin{array}{l}\text { Machine and process } \\
\text { engineering }\end{array}$ & -0.659 & 0.673 & 0.185 & 0.514 & -0.698 & 0.675 & -0.498 & 0.468 \\
\hline Electrical engineering & -1.064 & 0.692 & 0.031 & 0.539 & -1.024 & 0.671 & $-1.057 *$ & 0.546 \\
\hline Management consulting & -0.956 & 0.585 & 0.143 & 0.574 & -0.941 & 0.590 & -0.749 & 0.554 \\
\hline R\&D services & -1.078 & 0.667 & -0.244 & 0.698 & $-1.123 *$ & 0.672 & -0.670 & 0.551 \\
\hline$\tau^{2}$ & $1.338 * * *$ & 0.111 & & & $1.331^{* *}$ & 0.112 & & \\
\hline$\rho$ & $0.810 * * *$ & 0.127 & & & $0.681^{* *}$ & 0.191 & & \\
\hline Log likelihood & -183.16 & & & & -199.236 & & & \\
\hline
\end{tabular}

Note: Estimation method is conditional ML. $* * *$ denotes $99 \%$ significance, $* *$ denotes $95 \%$ significance, $*$ denotes $90 \%$ significance levels. 
The reference industry is industrial design. In the control rights equation, dummy variables were used for exports and R\&D investments instead of their intensities, because these were found to capture more of the variation than the intensity variables. However, other coefficients are not affected by this. Same results are obtained for the innovation output models with dummy or intensity variables. 


\section{Appendix}

Table A1 Descriptive statistics for estimation variables

\begin{tabular}{|llllll|}
\hline Variable & Mean & Std. dev. & Min. & Max. & Obs. \\
\hline IMPROVEMENT & 0.566 & 0.497 & 0 & 1 & 145 \\
NEW SERVICE & 0.483 & 0.501 & 0 & 1 & 145 \\
Log(EMPLOYEES) & 2.974 & 1.182 & 0 & 6.380 & 145 \\
BUSINESS GROUP & 0.414 & 0.494 & 0 & 1 & 145 \\
EXPORT INTENSITY & 0.125 & 0.267 & 0 & 1 & 145 \\
EXPORTS $>0$ & 0.331 & 0.472 & 0 & 1 & 145 \\
PROFITABILITY & 0.692 & 0.629 & 0 & 4.429 & 145 \\
AGE & 18.007 & 14.391 & 2 & 90 & 145 \\
R\&D INTENSITY & 0.063 & 0.344 & 0 & 4.000 & 145 \\
R\&D DEPARTMENT & 0.200 & 0.401 & 0 & 1 & 145 \\
R\&D INVESTMENTS $>0$ & 0.600 & 0.492 & 0 & 1 & 145 \\
HIGHER EDUCATION & 32.759 & 30.200 & 0 & 100 & 145 \\
POST GRAD EDUCATION & 2.462 & 6.895 & 0 & 50 & 145 \\
CONTROL RIGHTS & 4.069 & 1.517 & 0 & 6 & 145 \\
OUTPUT CONTROL RIGHTS & 2.210 & 0.812 & 0 & 3 & 145 \\
TO CLIENT & 1.276 & 0.722 & 0 & 2 & 145 \\
PARTIAL EXCLUSIVITY & 1.828 & 0.739 & 0 & 3 & 145 \\
INDEPENDENT & 1.372 & 0.716 & 0 & 3 & 145 \\
PROJECT DESIGN & 0.407 & 0.493 & 0 & 1 & 145 \\
QUALITY SYSTEM & & &
\end{tabular}


Table A2 Pairwise correlation matrix for estimation variables

\begin{tabular}{|c|c|c|c|c|c|c|c|c|}
\hline & 1 & 2 & 3 & 4 & 5 & 6 & 7 & 8 \\
\hline 1. IMPROVEMENT & 1 & & & & & & & \\
\hline 2. NEW SERVICE & $0.4113^{* *}$ & & & & & & & \\
\hline 3. Log(EMPLOYEES) & $0.2877 * *$ & $0.1748^{*}$ & 1 & & & & & \\
\hline 4. BUSINESS GROUP & $0.2740 * *$ & 0.119 & $0.4270 * *$ & 1 & & & & \\
\hline 5. EXPORT INTENSITY & -0.0613 & -0.1099 & 0.1005 & 0.1514 & 1 & & & \\
\hline 6. PROFITABILITY & 0.1544 & 0.0993 & -0.072 & 0.0416 & 0.0585 & 1 & & \\
\hline 7. AGE & $0.1753^{*}$ & $0.1867 *$ & $0.4117 * *$ & $0.2317 * *$ & -0.1322 & -0.0748 & 1 & \\
\hline 8. R\&D INTENSITY & -0.0329 & 0.1192 & 0.0162 & -0.0662 & -0.0056 & -0.0929 & -0.0441 & 1 \\
\hline 9. R\&D DEPARTMENT & $0.2213 * *$ & 0.0926 & 0.058 & 0.0027 & 0.1165 & -0.0066 & $-0.1583 *$ & $0.2025^{*}$ \\
\hline 10. HIGHER EDUCATION & 0.1169 & $0.1768^{*}$ & -0.0815 & 0.0105 & 0.0045 & 0.0768 & 0.0463 & 0.0503 \\
\hline 11. POST GRAD EDUC. & -0.0371 & -0.0742 & -0.1332 & -0.0476 & $0.1964 *$ & -0.0227 & -0.0863 & $0.2898 * *$ \\
\hline 12. CONTROL RIGHTS & -0.0154 & -0.1061 & 0.1409 & 0.1438 & -0.1662 & $-0.1927 *$ & -0.0247 & -0.0615 \\
\hline $\begin{array}{l}\text { 13. OUTPUT CONTROL TO } \\
\text { CLIENT }\end{array}$ & -0.0941 & -0.1266 & 0.0559 & 0.0587 & -0.0923 & -0.1346 & -0.0424 & $-0.2283 * *$ \\
\hline 14. PARTIAL EXCLUSIVITY & 0.0501 & -0.0143 & 0.1316 & 0.1429 & $-0.1798^{*}$ & -0.1389 & 0.0072 & 0.068 \\
\hline 15. PROJECT DESIGN & $0.1972 *$ & $0.1967 *$ & $0.1655^{*}$ & 0.0497 & -0.0103 & -0.0172 & 0.0191 & 0.0881 \\
\hline 16. INDEPENDENT & -0.1073 & -0.031 & $-0.1781^{*}$ & $-0.1692 *$ & $0.2332 * *$ & -0.0689 & $-0.1600 *$ & 0.0083 \\
\hline 17. QUALITY SYSTEM & -0.0471 & -0.0457 & $0.3313 * *$ & 0.0086 & $0.2148 *$ & $-0.2857 * *$ & $0.2043^{* *}$ & -0.0237 \\
\hline
\end{tabular}

Note: ** implies 99\% level of significance, $*$ implies $95 \%$ level of significance.

\begin{tabular}{|l|llllllll|}
\hline & 9 & 10 & 11 & 12 & 13 & 14 & 15 & 16 \\
\hline 9. R\&D DEPARTMENT & 1 & & & & & & & \\
10. HIGHER EDUCATION & 0.1057 & 1 & & & & & & \\
11. POST GRAD EDUC. & 0.06 & 0.035 & 1 & & & & & \\
12. CONTROL RIGHTS & 0.0119 & 0.0501 & -0.0928 & 1 & & & & \\
13. OUTPUT CONTROL TO & -0.1482 & -0.0103 & $-0.1751^{*}$ & $0.6518^{* *}$ & 1 & & & \\
CLIENT & 0.0774 & 0.0362 & 0.0082 & $0.8299 * *$ & $0.1671^{*}$ & 1 & & \\
14. PARTIAL EXCLUSIVITY & 0.1496 & 0.017 & 0.044 & -0.0977 & -0.1441 & -0.0196 & 1 & \\
15. PROJECT DESIGN & -0.0404 & -0.0159 & -0.0149 & -0.0833 & -0.0373 & -0.0904 & 0.0424 & 1 \\
16. INDEPENDENT & 0.1063 & 0.0012 & -0.0578 & 0.1122 & -0.0006 & 0.1334 & -0.0312 & -0.0102 \\
17. QUALITY SYSTEM & & & & & & & & \\
\hline
\end{tabular}


Table A3 Test for the endogeneity of control rights $(\mathrm{N}=\mathbf{1 4 5})$

\begin{tabular}{|l|ccc|ccc|}
\hline & \multicolumn{3}{|c|}{ IMPROVEMENT } & \multicolumn{3}{c|}{ NEW SERVICE } \\
\hline & Coeff. & Std.Err & $\begin{array}{l}\text { Marginal } \\
\text { effect }\end{array}$ & Coeff. & Std.Err. & $\begin{array}{l}\text { Marginal } \\
\text { effect }\end{array}$ \\
\hline Constant & 0.508 & 1.478 & 0.197 & $2.744^{*}$ & 1.411 & 1.094 \\
Log(employees) & $0.341^{* *}$ & 0.150 & 0.132 & $0.227 *$ & 0.131 & 0.090 \\
Business group & $1.004 * * *$ & 0.302 & 0.367 & $0.547 * *$ & 0.276 & 0.216 \\
Export intensity & $-1.257 * *$ & 0.566 & -0.488 & $-1.094 * *$ & 0.553 & -0.436 \\
Profitability & -0.016 & 0.261 & -0.006 & -0.327 & 0.253 & -0.130 \\
R\&D department & $1.041^{* * *}$ & 0.341 & 0.347 & 0.141 & 0.302 & 0.056 \\
R\&D intensity & -0.644 & 0.425 & -0.250 & 0.832 & 1.397 & 0.332 \\
Higher education & $0.010^{*}$ & 0.005 & 0.004 & $0.014 * * *$ & 0.005 & 0.006 \\
Post grad education & 0.024 & 0.021 & 0.009 & -0.029 & 0.023 & -0.011 \\
Control rights & $-0.621 * *$ & 0.317 & -0.241 & $-0.760 * *$ & 0.305 & -0.303 \\
Control rights residuals & $0.601 *$ & 0.327 & 0.233 & $0.584 *$ & 0.312 & 0.234 \\
\hline Advertising & 0.711 & 0.533 & 0.258 & -0.606 & 0.482 & -0.235 \\
Machine and process engineering & 0.497 & 0.618 & 0.184 & -0.526 & 0.545 & -0.205 \\
Electrical engineering & 0.276 & 0.614 & 0.104 & $-1.328 * *$ & 0.575 & -0.447 \\
Management consulting & 0.546 & 0.649 & 0.195 & -0.909 & 0.608 & -0.327 \\
R\&D services & 0.299 & 0.734 & 0.112 & -0.657 & 0.710 & -0.247 \\
\hline Log likelihood & -74.52 & & & -83.42 & & \\
\% correct predictions & $74.5 \%$ & & & $69.0 \%$ & & \\
\hline
\end{tabular}

Notes: ${ }^{* * *}$ denotes $99 \%$ significance, ${ }^{* *}$ denotes $95 \%$ significance, ${ }^{*}$ denotes $90 \%$ significance levels.

The reference industry is industrial design. The marginal effect of a binary variable is $\mathrm{P}(1)-\mathrm{P}(0)$. 


\section{References}

Aghion P, Tirole J. 1994. The Management of Innovation. Quarterly Journal of Economics 109(4): $1185-1210$

Anand BN, Khanna T. 2000. Do firms learn to create value? The case of alliances. Strategic Management Journal 21: 294-315

Asanuma B. 1989. Manufacturer-Supplier Relationships in Japan and the Concept of RelationSpecific Skill. Journal of the Japanese and International Economies 3: 1-30

Baker G, Gibbons R, Murphy KJ. 2002. Relational Contracts and the Theory of the Firm. Quarterly Journal of Economics 117(1): 39-84

Bakos JY, Brynjolfsson E. 1993. Information technology, incentives, and the optimal number of suppliers. Journal of Management Information Systems 10(2): 37-54

Cohen WM, Levinthal DA. 1989. Innovation and Learning: The Two Faces of R\&D. Economic Journal 99(Sept.): 569-596

DeBandt J. 1996. Business Services: Markets and Transactions. Review of Industrial Organization 11: 19-33

Dierickx I, Cool K. 1989. Asset Stock Accumulation and Sustainability of Competitive Advantage. Management Science 35(12): 1504-1511

Dyer JH. 1996. Specialized supplier networks as a source of competitive advantage: Evidence from the auto industry. Strategic Management Journal 17: 271-292

Dyer JH, Nobeoka K. 2000. Creating and Managing a High-Performance Knowledge-Sharing Network: The Toyota Case. Strategic Management Journal 21: 345-367

Dyer JH, Singh H. 1998. The Relational View: Cooperative Strategy and Sources of Interorganizational Competitive Advantage. Academy of Management Review 23(4): 660-679

Elfenbein D, Lerner J. 2003. Ownership and control rights in Internet portal alliances, 19951999. RAND Journal of Economics 34(2): 356-369

Foss K, Foss NJ. 2005. Resources and transaction costs: how property rights economics furthers the resource-based view. Strategic Management Journal 26(6): 541-553

Grossman SJ, Hart OD. 1986. The Costs and Benefits of Ownership: A Theory of Vertical and Lateral Integration. Journal of Political Economy 94(4): 691-719 
Hagedoorn J. 1993. Understanding the rationale of strategic technology partnering:

Interorganizational modes of cooperation and sectoral differences. Strategic Management Journal 14: 371-385

Hamel G. 1991. Competition for Competence and Inter-Partner Learning within International Strategicl Alliances. Strategic Management Journal 12: 83-103

Hamel G, Doz YL, Prahalad CK. 1989. Collaborate with your Competitors - and Win. Harvard Business Review 67(1): 133-139

Hansen MT, Nohria N, Tierney T. 1999. What's your strategy for managing knowledge? Harvard Business Review(March-April): 106-116

Hargadon A, Sutton RI. 1997. Technology Brokering and Innovation in a Product Development Firm. Administrative Science Quarterly 42: 716-749

Hart O. 1995. Firms, Contracts, and Financial Structure. Oxford University Press: Oxford

Hart O, Moore J. 1990. Property Rights and the Nature of the Firm. Journal of Political Economy 98(6): 1119-1158

Holmström B. 1985. The provision of services in a market economy. In RP Inman (Ed.), Managing the Service Economy - Prospects and Problems. Cambridge University Press: Cambridge

Kale P, Singh H, Perlmutter H. 2000. Learning and protection of proprietary assets in strategic alliances: Building relational capital. Strategic Management Journal 21: 217-237

Kogut B. 1988. Joint Ventures: Theoretical and Empirical Perspectives. Strategic Management Journal 9: 319-332

Leiponen A. 2006a. Managing Knowledge for Innovation: The Case of Business-to-Business Services. Journal of Product Innovation Management 23: 238-258

Leiponen A. 2006b. Organization of Knowledge Exchange: An Empirical Study of KnowledgeIntensive Business Service Relationships. Economics of Innovation and New Technology 15(4/5): 443-464

Lerner J, Merges RP. 1998. The Control of Technology Alliances: An Empirical Analysis of the Biotechnology Industry. Journal of Industrial Economics 46(2): 125-156

Levin RC, Klevorick AK, Nelson RR, Winter SG. 1987. Appropriating the Returns from Industrial Research and Development. Brookings Papers on Economic Activity No. 3(3): 783-820 
Löwendahl BR. 1997. Strategic Management of Professional Service Firms. Handelhöjskolens Forlag: Copenhagen

Maddala GS. 1983. Limited-Dependent and Qualitative Variables in Econometrics. Cambridge University Press: New York

Mairesse J, Mohnen P. 2002. Accounting for Innovation and Measuring Innovativeness: An Illustrative Framework and an Application. American Economic Review 92(2): 226-230

Miles I, Boden M. 2000. Introduction: Are Services Special? In I Miles, M Boden (Eds.), Services and the Knowledge-Based Economy: 1-20. Continuum: London

Miles I, Kastrinos N, Bilderbeek R, Hertog Pd. 1995. Knowledge-Intensive Business Services: Users, Carriers and Sources of Innovation: 103. European Innovation Monitoring System (EIMS)

Mowery DC, Oxley JE, Silverman BS. 1996. Strategic Alliances and Interfirm Knowledge Transfer. Strategic Management Journal 17: 77-91

O'Farrell PN. 1995. Manufacturing demand for business services. Cambridge Journal of Economics 19: 523-543

Oxley JE. 1997. Appropriability Hazards and Governance in Strategic Alliances: A Transaction Cost Approach. Journal of Law, Economics, \& Organization 13(2): 389-409

Oxley JE, Sampson RC. 2004. The Scope and Governance of International R\&D Alliances. Strategic Management Journal 25: 723-749

Pisano GP. 1989. Using Equity Participation to Support Exchange: Evidence from the Biotechnology Industry. Journal of Law, Economics and Organization 5(1): 109-126

Poppo L, Zenger T. 2002. Do formal contracts and relational governance function as substitutes or complements? Strategic Management Journal 23: 707-725

Reuer JJ, Arino A, Mellevigt T. forthcoming. Entrepreneurial Alliances as Contractual Forms. Journal of Business Venturing

Rivers D, Vuong QH. 1988. Limited Information Estimators and Exogeneity Tests for Simultaneous Probit Models. Journal of Econometrics 39: 347-366

Sampson RC. 2004. The Cost of Misaligned Governance in R\&D Alliances. Journal of Law, Economics \& Organization 20(2): 484-526

SF. 1998. Innovaatiotutkimus 1996. Statistics Finland: Helsinki

SF. 2000. Tiede ja Teknologia. Statistics Finland: Helsinki 
Sorensen JB, Stuart TE. 2000. Aging, Obsolescence, and Organizational Innovation. Administrative Science Quarterly 45(1): 81-112

Sundbo J. 1997. Management of Innovation in Services. Service Industries Journal 17(3): 432455

Teece DJ. 1986. Transactions Cost Economics and the Multinational Enterprise: An Assessment. Journal of Economic Behavior and Organization 7: 21-45

Teece DJ, Pisano G, Shuen A. 1997. Dynamic Capabilities and Strategic Management. Strategic Management Journal 18(7): 509-533

Tomlinson M. 2000. Information and Technology Flows from the Service Sector: a UK-Japan Comparison. In M Boden, I Miles (Eds.), Services and the Knowledge-Based Economy: 209-221. Continuum: London

Veugelers R, Cassiman B. 1999. Make and buy in innovation strategies: evidence from Belgian manufacturing firms. Research Policy 28: 63-80

Wernerfelt B. 1984. A Resource-Based View of the Firm. Strategic Management Journal 5: 171180

Wooldridge JM. 2002. Econometric Analysis of Cross Section and Panel Data. The MIT Press: Cambridge, MA 